Prawo do zapomnienia - ewolucja francuskiego modelu normatywnego deklaracji ryzyka ...

\title{
Prawo do zapomnienia - ewolucja francuskiego modelu normatywnego deklaracji ryzyka ubezpieczeniowego w sektorze bancassurance
}

Celem niniejszego artykułu jest przedstawienie instytucji prawa do zapomnienia, wynikajacej z nowelizowanego w 2016 roku francuskiego kodeksu zdrowia publicznego, oraz jej wpływu na obowiqzki informacyjne kandydatów do ubezpieczenia na życie.

Artykuł jest podzielony na dwie części. Część pierwsza została poświęcona francuskiej regulacji obowiqzków informacyjnych ubezpieczajacych w umowach ubezpieczenia na życie, w tym ich ewolucji pod wpływem rozwiqzań interpretacyjnych Cour de Cassation. Kształt obowiqzujacych przepisów został omówiony z odniesieniami do rozstrzygnięć francuskiego Sqqu Najwyższego. W drugiej części przedstawiono pokrótce dwie instytucje kodeksu zdrowia publicznego, które poprzedzaja prawo do zapomnienia, mianowicie zakaz dostępu do danych genetycznych oraz tajemnicę lekarskq. Następnie omówione zostało prawo do zapomnienia, zakres jego stosowania oraz treść tego prawa. We wnioskach porównano opisywanq instytucję z rozwiqzaniami prawnymi dostępnymi w polskim systemie prawnym.

Artykuł zawiera odniesienia do orzecznictwa francuskiego Sqdu Najwyższego oraz literatury w głównej mierze francuskojęzycznej, co znajduje swoje uzasadnienie w badanej tematyce.

Słowa kluczowe: prawo do zapomnienia, deklaracja ryzyka ubezpieczeniowego, ubezpieczenia na życie, prawo francuskie, bancassurance.

\section{Wprowadzenie}

Celem niniejszego artykułu jest przedstawienie francuskiej instytucji prawa do zapomnienia (fr. droit à l’oubli) jako efektu ewolucji zasad dotyczących współpracy przedkontraktowej w zakresie informowania ubezpieczyciela o ryzyku ubezpieczeniowym. Następnie, w kontekście tych zasad omówione zostaną trzy prokonsumenckie wyjątki: zakaz dostępu instytucji ubezpieczeniowych do danych genetycznych, rozkład ciężaru dowodu faktów nieujawnionych w deklaracji ubezpieczeniowej wraz z tajemnicą lekarską oraz prawo do zapomnienia. Ostatnia część artykułu 
będzie zawierać porównanie francuskiej i polskiej regulacji systemu deklaracji ubezpieczeniowej oraz zwięzłe wnioski.

Artykuł ten powstałjako owoc badań własnych autorki - z wykorzystaniem literatury polskiej i obcojęzycznej - zainspirowanych dyskusja, jaka miała miejsce podczas międzynarodowej konferencji naukowej „Oncologie et droit. Points de vue franco-polonais”, która odbyła się w dniach 9-10 listopada 2017 roku na Wydziale Prawa i Administracji Uniwersytetu Łódzkiego. Farida Arhab-Girardin w prelekcji poświęconej niedyskryminowaniu pacjentów onkologicznych w dostępie do usług bancassurance przedstawiła podstawowe elementy konstrukcji prawa do zapomnienia oraz zakres jego stosowania względem osób cierpiących z powodu chorób nowotworowych. Instytucja ta nie jest szeroko znana poza Francja, w związku z czym głównym celem niniejszego artykułu jest przybliżenie jej polskiemu środowisku prawa ubezpieczeniowego.

\section{Francuski model deklaracji ryzyka ubezpieczeniowego}

Wobec obecnego postępu medycyny i możliwości diagnostyki chorób śmiertelnych stan wiedzy ubezpieczającego ma szczególne znaczenie w momencie zawierania umowy ubezpieczenia osobowego, kiedy ubezpieczajacy składa oświadczenie wiedzy o potencjalnych lub istniejących schorzeniach, mogacych powodować zaistnienie wypadku ubezpieczeniowego i skutkować realizacja odpowiedzialności ubezpieczyciela.

Francuski ustawodawca bardzo rygorystycznie uregulował obowiązki informacyjne ubezpieczającego. Wydaje się jednak, że przez pewien czas osoby chore onkologicznie czy przewlekle w większym stopniu były narażone na dyskryminację z powodu choroby, która może być bariera w dostępie do usług ubezpieczeniowych czy bankowych. Obiektywnie większy dostęp do wiedzy na temat choroby i jej konsekwencji nie czyni bowiem pacjenta silniejszą strona stosunku prawnego, a może wręcz znacznie osłabić jego pozycję wobec przedsiębiorcy jakim jest ubezpieczyciel. Wiedza granicząca z pewnością - wypływająca z badań diagnostycznych - może być dla ubezpieczyciela powodem odmowy objęcia ochroną ubezpieczeniową lub zaproponowania umowy na zdecydowanie niekorzystnych dla ubezpieczajacego warunkach.

Ponieważ ekonomicznym sensem umowy ubezpieczenia jest przejęcie odpowiedzialności za ryzyko przy jednoczesnej redukcji kosztów tej odpowiedzialności, umowa ubezpieczenia jest nazywana kontraktem najwyższego zaufania. Zaufanie to strony budują na podstawie przekazywanych sobie informacji. Stąd też wynika fundamentalny charakter obowiązków informacyjnych stron.

\subsection{Ubezpieczenie - umowa losowa}

Art. 1964 francuskiego kodeksu cywilnego (dalej: fr. k.c.), uchylony art. 5 rozporządzenia nr 2016-131 z dnia 10 lutego 2016 roku, zwanego wielką reformą zobowiązań ${ }^{1}$, wskazywał, że umowa ubezpieczenia zaliczona jest przez ustawodawcę do umów losowych, tzn. takich, w których wzajemne świadczenia stron, zarówno co do korzyści, jak i strat, zastrzeżonych dla obu lub też tylko dla jednej ze stron, zależą od niepewnego wydarzenia. Definicja legalna umowy losowej

1. Ordonnance $\mathrm{n}^{0}$ 2016-131 du 10 février 2016 portant réforme du droit des contrats, du régime général et de la preuve des obligations. 
Prawo do zapomnienia - ewolucja francuskiego modelu normatywnego deklaracji ryzyka ...

we francuskim kodeksie cywilnym - choć zasadniczo nie uległa zmianie - przeniesiona została do art. 1108 fr. k.c. Przepis ten nie zawiera jednak katalogu wskazującego wprost umowę ubezpieczenia jako przykład umowy losowej.

Te zmiany maja jednak charakter raczej techniczny, zważywszy, że co do meritum Cour de cassation nadal ujmuje l'aléa - przez co należy rozumieć 'przypadek, ryzyko' - jako samą istotę umowy ubezpieczenia ${ }^{2}$. W prawie francuskim zatem umowa ubezpieczenia jest, ze swej natury, umową losowa. ${ }^{3}$ Podobnie jak w prawie polskim przedmiotem umowy ubezpieczenia nie może być ryzyko, o którym ubezpieczający wie, że już się spełniło.

\subsection{Ewolucja prawa ubezpieczeń - orzecznictwo francuskiego Sądu Najwyższego}

We Francji system deklaracji ryzyka ubezpieczeniowego opierał się początkowo - tak jak w systemach anglosaskich ${ }^{4}$ - na obowiązku deklaracji spontanicznej. Ustawa z 13 lipca 1930 roku o ubezpieczeniach lądowych pojazdów mechanicznych ${ }^{5}$ - loi Godart - dała podwaliny pod późniejszy kodeks ubezpieczeń i oznaczała obowiązek informacyjny ubezpieczającego bardzo szeroko. Art. 113-2 francuskiego kodeksu ubezpieczeń (dalej: fr. k.u.) z 1976 roku w dawnym brzmieniu był identycznym powtórzeniem art. 15 loi Godart i nakładał na ubezpieczającego obowiązek dokładnego przekazania w momencie zawarcia umowy informacji o wszystkich znanych okoliczności, które pozwoliłyby ubezpieczycielowi ocenić ryzyko, jakie przejmuje. Nawet zakładając tu pewne zezwolenie francuskiego ustawodawcy na subiektywizm ubezpieczającego w wyborze informacji potrzebnych dla zawarcia umowy ubezpieczenia, przepis ten nakładał na ubezpieczajacych praktycznie nieograniczony obowiązek informacyjny. ${ }^{6}$ Francuski Sąd Najwyższy uznał jednak, że takie ukształtowanie deklaracji ubezpieczeniowej jest zbyt szerokie i zagraża bezpieczeństwu prawnemu ubezpieczającego.

Pierwsze orzeczenie ograniczające system deklaracji spontanicznej francuski Sąd Najwyższy wydał w 1985 roku, rozstrzygając sprawę dot. zatajenia przez ubezpieczającego kierowcę faktu notorycznego braku prawa jazdy, ucieczek z miejsca wypadku itp. Sąd uznał, że w tej sprawie redakcja formularza deklaracji ubezpieczeniowej nie wskazywała na fakt, by ubezpieczyciel był zainteresowany tego rodzaju informacjami, i w związku z tym przemilczenie przez ubezpieczajacego jego przeszłości nie miało charakteru umyślnego w rozumieniu art. 113-8 fr. k.u. Fragment uzasadnienia tego wyroku Są Najwyższy powtórzył w orzeczeniu z 17 października 1995 roku sygn. 92-19-018?. W tym przypadku sprawa dotyczyła sporu o wypłatę świadczenia ubezpieczeniowego za kradzież samochodu, w którym ubezpieczyciel zarzucał nieudzielenie przez ubezpieczającego informacji o sposobie nabycia samochodu i innych okolicznościach dotyczących jego

2. Cour de cassation, $2^{\mathrm{e}}$ chambre civile,$?$ octobre $2010, \mathrm{~N}^{0}$ de pourvoi: $10-30233$.

3. Rapport annuel 2011: Le risque, [red.] Jacques Moury, Cour de Cassation, La Documentation française, Paris, 2011, s. 226.

4. E. Kowalewski, Umowa ubezpieczenia, Oficyna Wydawnicza Branta, Bydgoszcz-Toruń 2002, s. 89.

5. Tekst ustawy Godart dostępny na stronie Bibliothèque Nationale de France pod adresem https://gallica.bnf. fr/ark:/12148/bpt6k65337722/f18.item.r=apprécier.zoom [dostęp: 4.07.2018].

6. Rapport annuel $2011 \ldots$, s. 229.

?. $1^{\mathrm{e}}$ Civ., du 17 octobre 1995 , pourvoi no 92-19.018, inédit. 
wartości. Sędziowie I izby cywilnej stwierdzili, podobnie jak w uzasadnieniu z 1985 roku, że prawdziwość i dokładność deklaracji ubezpieczającego oceniać należy w świetle stawianych mu pytań.

W międzyczasie, za sprawą loi Bérégovoy z 1989 roku, francuski ustawodawca, idąc za interpretacją wyznaczona przez Sąd Najwyższy, zmienił obowiązek informacyjny ubezpieczającego. Art. 113-2 ust. 2 fr. k.u. stanowi od tej pory, że kandydat do ubezpieczenia musi odpowiadać dokładnie na pytania ubezpieczyciela, które moga przybrać w szczególności postać formularza deklaracji ryzyka ubezpieczeniowego wypełnianego przed zawarciem umowy. Jednocześnie wydaje się, że nie ma ogólnego zakazu spontanicznego deklarowania okoliczności, jakie mogą być istotne dla ubezpieczyciela w ocenie ryzyka ubezpieczeniowego. Ubezpieczający może zatem swobodnie uzupełnić informacje jego zdaniem istotne ponad kwestie poruszone przez ubezpieczyciela w formularzu.

\subsection{Obowiązki informacyjne - przepisy ogólne francuskiego kodeksu cywilnego}

Poza przepisami fr. k.u. nie można pominąć przedkontraktowych obowiązków informacyjnych, majacych walor klauzuli porządku publicznego - jak stanowi art. 1104 fr. k.c. Obowiązki te wynikaja z przepisów reformowanej w 2016 roku części ogólnej zobowiązań. Art. 1112-1 fr. k.c. stanowi, że „ta ze stron, która zna informację o znaczeniu istotnym dla zgody drugiej strony, musi ją o niej poinformować, jeżeli jest ona w usprawiedliwionej niewiedzy co do tej informacji lub ufa swojemu kontrahentowi." Informacja ta musi mieć po pierwsze decydujące znaczenie dla drugiej strony [fr. importance déterminante] - nie jest to tożsame z zakresem essentialia negotii, dlatego też francuska doktryna proponowała inne określenia, jak np. informacje adekwatne ${ }^{10}$. Po drugie, obowiązek informacyjny odpada, jeśli strona jest w stanie usprawiedliwionej niewiedzy - fr. ignorance légitime. Sprawa obowiązków informacyjnych opiera się zatem na istnieniu dobrej wiary stron, i takie rozumowanie powiela fr. k.u., wskazując na sankcje za naruszenie obowiązku deklaracji ryzyka. W pewnych źródłach mówi się o zasadzie nieasymetrii informacji ${ }^{11}$ ( fr. le principe de non-asymétrie de l'information].

\subsection{Sankcje za naruszenie obowiązku deklaracji ryzyka ubezpieczeniowego}

Jak już wskazano, sankcje za naruszenie obowiązku informacyjnego w deklaracji ryzyka ubezpieczeniowego sa dwojakie i zależą w zasadniczej mierze - podobnie jak w prawie polskim - od stanu świadomości kandydata do ubezpieczenia.

Francuski kodeks ubezpieczeń reguluję tę kwestie dość szczegółowo, podając arsenał konsekwencji wynikających z nieprawidłowego złożenia deklaracji.

8. Loi n 89-1009 du 31 décembre 1989 renforçant les garanties offertes aux personnes assurées contre certains risques.

9. B. Marlewska, Odpowiedzialność przedkontraktowa - reforma francuskiego prawa zobowiqzań z 2016 r., „Gdańskie Studia Prawnicze” 2018, tom XXXIX Współczesne problemy prawa prywatnego, s. 399-41?.

10. M. Fabre-Magnan, Droit des obligations, T. 1: Contrat et engagement unilatéral, Presses Universitaires de France, Paris 2016, s. 264.

11. Assurance et VIH/SIDA, Rapport d'activité du Conseil national du sida du 20 septembre 1999, La Documentation française, Paris 2001, s. 46 - dostępny pod adresem http://www.ladocumentationfrancaise.fr/var/ storage/rapports-publics/044000249.pdf [dostęp: 05.09.2018]. 
Prawo do zapomnienia - ewolucja francuskiego modelu normatywnego deklaracji ryzyka ...

Naturalną konsekwencja potwierdzonego przez orzecznictwo Cour de cassation losowego charakteru umowy ubezpieczenia jest brak odpowiedzialności ubezpieczyciela za czyny popełnione umyślnie. Już ogólny art. 1113-1 fr. k.u. stanowi, że za szkody i krzywdy wynikające z przypadków losowych lub spowodowane błędem ubezpieczonego odpowiada ubezpieczyciel - chyba że postanowienia umowy wprost i jasno to wykluczaja. Ubezpieczyciel natomiast nie odpowiada nigdy, jeśli szkody wynikają z umyślnej winy lub zostały podstępnie wywołane przez ubezpieczonego.

Co do wyjątków wskazanych w polisie ubezpieczeniowej - Cour de cassation rozwinałł na podstawie tego przepisu ochronną dla konsumentów linię orzeczniczą; wyjątki odpowiedzialności ubezpieczyciela muszą odnosić się do faktów konkretnych, muszą być wskazane jasno, wprost, i nie można ich dorozumiewać ${ }^{12}$. Przykładowo: nieważna będzie klauzula odnosząca się do staranności ubezpieczającego mienie, który ma dbać o utrzymanie i bezpieczeństwo budynku „jak dobry ojciec rodziny" (fr. bon père de famille) - ponieważ zakres odpowiedzialności nie jest tu wprost i jasno oznaczony. ${ }^{13}$ Okoliczności wyłączające odpowiedzialność ubezpieczyciela powinny stanowić w polisie katalog zamknięty - nie będzie zatem ważne wyłączenie odpowiedzialności ubezpieczyciela za wszelkie choroby i następstwa zdrowotne wynikające z nadużywania alkoholu czy substancji psychotropowych dostępnych bez recepty ${ }^{14}$. Wyłączenia powinny być określone z maksymalną szczegółowością, czego doskonałym przykładem jest uznanie przez francuski Sąd Najwyższy określenia „choroby przenoszone droga płciowa”” za zbyt ogólne i niewystarczająco jasne. Zdaniem Sąu należało wskazać konkretne jednostki chorobowe, a nie sposób zakażenia ${ }^{15}$. Wyłączenia odpowiedzialności nie mogą również wypaczać sensu umowy ubezpieczenia i wyłączać odpowiedzialności ubezpieczyciela w maksymalnym zakresie, nawet jeśli sa jasne, konkretne i wskazane w wyczerpujący sposób.

Ogólny przepis art. 113-1 fr. k.u. jest refleksem cywilistycznie rozumianych błędu i podstępu, będących podstawą do uznania nieważności umowy, czego dowodem jest już styl redakcji przepisów szczególnych kodeksu ubezpieczeń. Art. 113-8 fr. k.u. ustanawia specjalne sankcje za naruszenie obowiązku informacyjnego, „niezależnie od zwykłych przyczyn nieważności”. Chodzi tu o względna nieważność, wywoływaną przez przypadkowy czy podstępny błąd uniemożliwiający porozumienie między stronami i świadomą zgodę. Umowa ubezpieczenia zawarta pod wpływem istotnego błędu czy podstępu będzie wzruszalna - w terminie 5 lat od momentu, gdy uprawniony powziął lub mógł z zachowaniem należytej staranności powziąć wiadomość o okoliczności błędu czy podstępu ${ }^{16}$.

Regulacja szczególna z art. 113-8 fr. k.u. przewiduje bardziej radykalne konsekwencje naruszenia obowiązków informacyjnych. Jak już wspomniano, są one dwojakie, i uzależnione od dobrej wiary ubezpieczającego. W przypadku istnienia złej wiary, objawiającej się świadomym przemilczeniem lub zamierzenie fałszywą deklaracja kandydata do ubezpieczenia, jeśli zmieniają one przedmiot ryzyka lub wpływaja na opinię ubezpieczyciela co do ryzyka - umowa ubezpieczenia jest bezwzględnie nieważna. Co istotne, nieważność ta ma miejsce nawet jeśli fakty zatajone czy zniekształcone przez ubezpieczającego pozostają bez związku ze zdarzeniem ubezpieczeniowym.

\footnotetext{
12. Rapport annuel $2011 \ldots$, s. 237.

13. $1^{\text {re }}$ Civ., 12 mai 1993 , pourvoi no $91-17.010$.

14. $2^{\mathrm{e}}$ Civ., 18 janvier 2006, pourvoi no $04-17.872$.

15. $1^{\text {re }}$ Civ., 4 mai 1999 , pourvoi no $97-16.924$.

16. Art. 2224 fr. k.c.
} 
Oznacza to, że ustawodawca francuski stosunkowo dotkliwie - bo z pominięciem związku przyczynowego, typowego dla zasady winy - sankcjonuje nieprawdomówność ubezpieczającego. Ocena poprawności deklaracji dokonuje się in abstracto. Można zatem powiedzieć o nieprawidłowościach w deklaracji, jeśli mają one związek z przedmiotem ryzyka albo z opinią, jaką ubezpieczyciel mógł wyrobić sobie o ryzyku, gdyby był poinformowany prawidłowo. Niepełna lub kłamliwa deklaracja nie pozwala ubezpieczycielowi na uzyskanie pełnego obrazu ryzyka, które będzie ubezpieczać, i tym samym nie wystapi w tym momencie świadoma zgoda strony umowy na jej zawarcie. Wyrokiem z 15 lutego 2007 roku francuski Sąd Najwyższy potwierdził, że ten przepis nie znajdzie zastosowania w sytuacji, kiedy ubezpieczyciel doszedł na podstawie deklaracji - zarzucając jej w późniejszym postępowaniu nieprawidłowości - do błędnych wniosków i dokonał błędnej oceny ryzyka, jednak przyczyna błędu nie tkwiła w deklaracji, lecz w nieprawidłowym rozumowaniu ubezpieczyciela. ${ }^{17}$ Nie zwalnia to ubezpieczającego z prawdomówności w odpowiadaniu na formularz ${ }^{18}$.

Druga możliwościa jest okoliczność w której niezgodna z prawdą deklaracja ze strony ubezpieczającego nie wynika z jego złej wiary. Art. 1113-9 fr. k.u. nie mówi wprost o „dobrej wierze” ubezpieczającego, ale o sytuacji w której jego status jest w tym zakresie niejasny, a złej wiary nie da się ustalić. Przewidziano w tym miejscu dwa „scenariusze” postępowania. Po pierwsze, jeśli stwierdzenie konkretnej okoliczności za niezgodną z prawdą miało miejsce przed wystapieniem jakiegokolwiek zdarzenia ubezpieczeniowego w okresie objętym ochroną, ubezpieczyciel może utrzymać umowę, zwiększając jednocześnie stawkę składki ubezpieczeniowej za zgodą ubezpieczającego, albo - alternatywnie - wypowiedzieć umowę w terminie 10 dni od zawiadomienia - wysłanego do ubezpieczonego listem poleconym - o stwierdzeniu niezgodności z prawdą deklaracji ubezpieczeniowej. Decydując się na rozwiązanie umowy, ubezpieczyciel zobowiązany jest zwrócić sumę składek uiszczonych za okres, w którym ochrona ubezpieczeniowa trwałaby, gdyby jej nie wypowiedział. Drugi wariant postępowania obejmuje przypadek stwierdzenia niezgodności deklaracji z prawda po wystapieniu wypadku ubezpieczeniowego, należność ze świadczenia ubezpieczeniowego jest wówczas zmniejszona proporcjonalnie do składek rzeczywiście opłaconych względem składek należnych w oparciu o prawidłowo i dokładnie ustalone ryzyko ubezpieczeniowe.

Podsumowując, należy stwierdzić, że taki mechanizm odpowiedzialności za nieprawidłowość deklaracji ubezpieczeniowych jest dość elastyczny i w znaczącym stopniu chroni konsumenta usługi ubezpieczeniowej. System formularza deklaracji ubezpieczeniowej i zasada odpowiedzi na pytania w nim zawarte zdejmują z ubezpieczającego ciężar odpowiedzialności za dobór informacji, co z kolei ogranicza zbyt swobodny dostęp do zarzutu przemilczenia przez ubezpieczajacego kwestii istotnych dla ubezpieczyciela. Odpowiedzialność na zasadach ogólnych, przewidzianych dla klasycznych spraw dotyczących wad oświadczenia woli nie jest wykluczona, jednak w większości przypadków, zgodnie z zasadą lex specialis derogat legi generali, odpowiedzialność zafunkcjonuje w warunkach art. 1113-1, 1113-8 i 1113-9 fr. k.u.

Francuskie prawo ubezpieczeń przeszło ewolucję - od systemu deklaracji spontanicznej do systemu „odpowiedzi na pytania”, jako bardziej bezpiecznego dla konsumenta usługi ubezpieczeniowej - ubezpieczającego, gdyż system ten eliminuje możliwość podniesienia przez ubezpieczyciela zarzutu niepodania informacji koniecznych. Innymi słowy, ubezpieczyciel jako przedsiębiorca, szacując ryzyko ubezpieczeniowe, powinien działać z należytą starannością i to

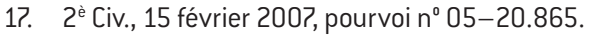

18. $1^{\text {re }}$ Civ., 22 mai 2002, pourvoi $n^{\circ} 00-12.419$. 
Prawo do zapomnienia - ewolucja francuskiego modelu normatywnego deklaracji ryzyka ...

w jego interesie będzie stworzenie odpowiedniego formularza deklaracji ubezpieczeniowej. Ciężar ten nie spoczywa już na ubezpieczającym.

\section{Prawo do zapomnienia jako wyjątek od zasady deklaracji ubezpieczeniowej}

Rozpoczynając omówienie problematyki prawa do zapomnienia w prawie francuskim, należy zaznaczyć, że nie jest to prawo do bycia zapomnianym w rozumieniu ogólnego rozporządzenia o ochronie danych ${ }^{19}$ z 2016 roku, które daje możliwość żądania usunięcia lub zaprzestania przetwarzania danych przechowywanych przez ich administratora. Jest to raczej prawo do pominięcia, przemilczenia pewnych informacji, które w klasycznym ujęciu obowiązków przedkontraktowych ubezpieczającego stanowiłoby wprowadzenie ubezpieczyciela w błąd, będąc jednocześnie przesłanką nieważności całej umowy ubezpieczenia. Dostęp do informacji o stanie zdrowia, będących danymi osobowymi o charakterze wrażliwym, jest konieczny dla ubezpieczyciela w celu zbudowania obrazu ryzyka, jakie ma ponieść w razie zaistnienia wypadku ubezpieczeniowego. Dostęp ten nie jest jednak nieograniczony. Zaufanie między stronami umowy ubezpieczenia buduje się od samego początku na podstawie przekazywanych informacji. W interesie ubezpieczyciela ponoszącego odpowiedzialność o charakterze gwarancyjnym jest uzyskanie jak największej ilości informacji o ubezpieczonym, tak by najdokładniej oszacować ryzyko ubezpieczeniowe. Tymczasem prawo do zapomnienia jest kolejnym, obok klasycznego mechanizmu tajemnicy lekarskiej i zakazu dostępu ubezpieczycieli do badań genetycznych, wyjątkiem przewidzianym przez francuskie prawo w procesie budowania zaufania między ubezpieczycielem i ubezpieczajacym.

\subsection{Zakaz dostępu do danych genetycznych}

Ocena ryzyka ubezpieczeniowego opiera się standardowo na danych statystycznych, pozwalajacych na zbudowanie „grup ryzyka” i określenie oferty ubezpieczeniowej do konsumentów znajdujących się w danej grupie. Obecnie - w dobie medycyny spersonalizowanej - zauważalna jest indywidualizacja oceny ryzyka. W szczególności wiedza, jaką można posiaść na temat własnego stanu zdrowia dzięki wykonaniu badań genetycznych, graniczy z pewnością i jako taka wypaczałaby sens umowy ubezpieczenia jako umowy losowej. Jak już podkreślał francuski Sąd Najwyższy, ryzyko jest kwintesencją umowy ubezpieczenia, i jako takie nie może zostać z niej wyeliminowane.

Myśl ta łączy się jednocześnie z duchem kodeksu zdrowia publicznego, który bardzo jasno wskazuje w art. 1141-1, że przedsiębiorcy oferujący ubezpieczenia zdrowotne i na życie nie moga brać pod uwagę wyników badań genetycznych kandydata do ubezpieczenia, nawet jeśli przekaże je on dobrowolnie. Innymi słowy, nie mogą uzyskiwać żadnych informacji związanych z testami genetycznymi i ich wynikami, jak również nie moga żądać od swoich klientów poddania się testom genetycznym przed zawarciem umowy oraz przez cały czas jej trwania. Przepis ten został

19. Rozporządzenie Parlamentu Europejskiego i Rady (UE) 2016/679 z dnia 27 kwietnia 2016 r. w sprawie ochrony osób fizycznych w związku z przetwarzaniem danych osobowych i w sprawie swobodnego przepływu takich danych oraz uchylenia dyrektywy 95/46/WE. 
wprowadzony ustawą ${ }^{20}$ będącą odpowiednikiem polskiej ustawy o prawach pacjenta i Rzeczniku Praw Pacjenta i jako taki stanowi wyraźny zakaz dyskryminacji w dostępie do ubezpieczenia ze względu na genotyp i wynikające z niego konsekwencje zdrowotne. Jest to zresztą także czyn zabroniony w rozumieniu francuskiego kodeksu karnego, którego art. 225-2 przewiduje zagrożenie karne do 3 lat pozbawienia wolności i 45000 euro grzywny. Predyspozycje genetyczne są zatem wykluczone z zakresu oceny ryzyka ubezpieczeniowego. Należy ocenić tę regulację jako zdecydowanie korzystną dla pacjentów, gdyż jak wynika z badań przeprowadzanych w Wielkiej Brytanii, częstokroć ubezpieczyciele mający dostęp do wyników badań genetycznych interpretuja je w nieprawidłowy sposób ${ }^{21}$. Brak dostępnych badań na temat stanu wiedzy społeczeństwa czy też poszczególnych grup zawodowych z zakresu medycyny genetycznej. Na tym tle zakaz dostępu do danych genetycznych jest przejawem pewnego interwencjonizmu prawa publicznego w umowę ubezpieczenia, wywodząca się z prawa prywatnego. Przedstawiciele francuskiej doktryny prawa zdrowia publicznego argumentują, że taka prokonsumencka postawa ustawodawcy jest uzasadniona, gdyż dostęp do ubezpieczenia umowy umożliwiającej zakup nieruchomości lokalowej ma charakter prawa podstawowego (fr. droit fondemental), ze względu na konstytucyjny charakter prawa do posiadania mieszkania. ${ }^{22}$

\subsection{Dostęp do danych zdrowotnych a tajemnica lekarska}

Zgodnie z art. $1353^{23}$ fr. k.c., zasada rozkładu ciężaru dowodu nakazuje, by to ubezpieczyciel udowodnił ubezpieczającemu, że deklaracja ryzyka ubezpieczeniowego była niezgodna z prawda. Ubezpieczyciel chcący ustalić obiektywne okoliczności związane ze stanem zdrowia ubezpieczonego ma zatem dwie możliwości. Może oprzeć się na zgromadzonej przez siebie dokumentacji medycznej lub - jeśli jej nie posiada -starać się uzyskać dostęp do jego dokumentacji medycznej. Ten interes koliduje z kolei z prawem pacjenta do prywatności, na straży którego stoi tajemnica lekarska, w związku z czym pojawiały się pewne zarzuty, że jest ona furtką dla osób naruszających obowiązki informacyjne z art. 113-8 fr. k.u. ${ }^{24}$ Zgodnie z art. 4 kodeksu deontologicznego lekarzy oraz art. R4127-4 kodeksu zdrowia publicznego, tajemnica lekarska obejmuje wszystko, czego lekarz dowiedział się o pacjencie w związku z wykonywaniem zawodu, nie tylko to, co zostało mu wyraźnie zakomunikowane, ale także to, co sam zaobserwował czy zrozumiał. Tajemnica lekarska ma w prawie francuskim walor klauzuli porzạdku publicznego, niemniej w razie kolizji interesów powołanie się na niąjest możliwe w wypadku istnienia uzasadnionego prawnie interesu, który podlega ocenie sądu. Jest to trwała interpretacja oparta o orzeczenie francuskiego Sądu Najwyższego z 15 czerwca 2004 roku w sprawie ubezpieczyciela, który dochodził, czy choroba będąca przyczyną śmierci ubezpieczonego dotykała go już przed zawarciem umowy ubezpieczenia na życie, czy

20. La loi n²002-303 du 4 mars 2002 relative aux droits des malades.

21. L. Low, S. King, T. Wilkie, Genetic discrimination in life insurance: empirical evidence from a cross sectional survey of genetic support groups in the United Kingdom, „General Practice”, vol. 31?, The BMJ Publishing Group 1998, s. 1635.

22. A. Laude, B. Mathieu, D. Tabuteau, Droit de la santé, Presses Universitaires de France, Paris 2012, s. 696.

23. „Celui qui réclame l'exécution d'une obligation doit la prouver." - ten, który domaga się wykonania zobowiązania, musi je udowodnić (tłum. aut.).

24. H. Groutel, Preuve de la déclaration inexacte du risque et secret médical, „Médecine \& Droit” 2004, no 68, , s. $105-11$ ? 
Prawo do zapomnienia - ewolucja francuskiego modelu normatywnego deklaracji ryzyka ...

też później. Śmierć miała miejsce 3 miesiące po zawarciu umowy i ubezpieczyciel podejrzewał, że ubezpieczający zataił fakt choroby (ang. pre-existing medical condition). Sąd powołał biegłego sądowego, który zwrócił się do lekarza medycyny pracy. Ten jednak podniósł wiążąca go tajemnicę lekarską. Sąd stwierdził, że o ile sąd może przekazać biegłemu pełną dokumentację, niezbędną do dokonania konsultacji, o tyle nie może zmusić lekarza do wyjawienia informacji objętych tajemnicą lekarską. ${ }^{25}$ Każdorazowo sąd powinien jednak oceniać, czy argumentowanie na rzecz tajemnicy lekarskiej służy bezpodstawnemu uniemożliwieniu ubezpieczycielowi dochodzenia prawdy, czy też istnieje rzeczywisty interes prawnie chroniony przez tajemnicę. Sąd Najwyższy położył zatem nacisk na uznanie sędziego, co w żaden sposób nie strukturyzuje mechanizmu dowodowego, jest to jednak rozwiązanie najbardziej elastyczne, dogodne dla rozstrzygnięć ad casum, w szczególności gdy chodzi o kwestie tak niełatwe do uchwycenia, jak dobra lub zła wiara strony²6.

\subsection{Prawo do zapomnienia}

Prawo do zapomnienia to flagowy projekt rządowego programu reformy zdrowotnej Plan Cancer III 2014-2019. Geneza tego mechanizmu wywodzi się z wczesnych lat 90., kiedy ustanowiono pierwsze zasady ochrony prywatności osób seropozytywnych w dostępie do ubezpieczenia ${ }^{27}$. W 2006 roku przyjęto konwencję AERAS (fr. une convention nationale AERAS) opracowaną na podstawie zasad dobrej praktyki ubezpieczeniowej, mająca za zadanie ułatwić osobom z poważnym ryzykiem zdrowotnym (fr. un risque aggravé) - w powodu przewlekłej choroby czy niepełnosprawności - dostęp do kredytu. Skrót AERAS to lapidarne ujęcie ratio legis tej konwencji - Ubezpieczać i Pożyczać z Poważnym Ryzykiem Zdrowotnym (fr. AERAS: S'Assurer et Emprunter avec un Risque Aggravé de Santé]. Jak wskazała w swoim wystapieniu Farida Arhab-Girardin, konwencja ta ma charakter wielostronny, obowiązuje ona zarówno organy państwowe, instytucje kredytowe i ubezpieczeniowe, jak i stowarzyszenia pacjentów oraz osób niepełnosprawnych ${ }^{28}$. Główną zasługa konwencji jest wszczęcie debaty publicznej nad problemem „życia po raku”29, którego socjoekonomicznym ciężarem jest także wyższe ryzyko ubezpieczeniowe i trudniejszy ekonomicznie dostęp do ubezpieczenia.

Od 26 stycznia 2016 roku prawo do zapomnienia jest także instytucją skodyfikowaną, umiejscowioną bezpośrednio za zakazem dostępu do danych genetycznych, mianowicie w art. 11412-1141-6 francuskiego kodeksu zdrowia publicznego (dalej: fr. k.z.p.), wprowadzonych ustawa o modernizacji systemu zdrowia. ${ }^{30}$ Nie do końca czytelny jest ostateczny kształt prawa do zapomnienia i trudno powiedzieć, czy zarówno w przypadku konwencji AERAS, jak i kodeksu zdrowia publicznego mowa jest o tej samej instytucji. ${ }^{31}$

25. Cour de Cassation, Chambre civile 1, du 15 juin 2004, pourvoi no. 01-02.338.

26. H. Groutel, op. cit., s. 105.

27. C. Torregosa, C. Gesbert, M. de Fallois, M.-F. Mamzer, Quel oubli pour les patients atteints de cancer?, „Ethics, Medicine and Public Health" 2017, nr 3, s. 108.

28. M. Schneider, Le plan cancer 2, „Oncologie” 2011, nr 13, s. 294.

29. M. Mesnil, What do we mean by the right to be forgotten ? An analysis of the French case study from a lawyer's perspective, „Journal of Cancer Policy” 2018, nr 15, s. 123.

30. Loi $n^{0} 2016-41$ du 26 janvier 2016 de modernisation de notre système de santé, JORF n0022 du 27 janvier 2016.

31. M. Mesnil, op. cit., s. 125. 


\subsubsection{Zakres stosowania prawa do zapomnienia}

Prawo do zapomnienia znajdzie swoje zastosowanie w momencie wypełniania formularza deklaracji ubezpieczeniowej przez osobę pragnącą ubezpieczyć inną czynność cywilnoprawną, np. umowę kredytu, jednak wyłącznie wtedy, gdy stan zdrowia tej osoby przedstawia poważne ryzyko i wniosek o objęcie ochroną ubezpieczeniową nie może być rozpatrywany w świetle ogólnych warunków ubezpieczenia - co do gwarancji ochronnych i wysokości składki. 0 jakie czynności chodzi? Ujmując art. L1141-2 fr. k.z.p. funkcjonalnie, sensem prawa do zapomnienia jest „ułatwienie dostępu do pożyczek”, natomiast z tego samego przepisu wynika, że jego adresatem są wszelkie instytucje kredytowe. Farida Arhab-Girardin podkreśliła, że prawo do zapomnienia ma ułatwić dostęp do ubezpieczenia wszelkich czynności, których funkcjajest korzystanie z cudzego kapitału, zatem nie tylko do pożyczki, ale także kredytów konsumenckich, kredytów hipotecznych czy kredytów dla przedsiębiorców ${ }^{32}$.

Zakres podmiotowy obejmuje zatem zawsze konsumentów usług bankowych, będacych jednocześnie pacjentami z powodu poważnych przewlekłych chorób, takich jak nowotwory, mukowiscydoza, czy będących nosicielami wirusów HBV, HCV czy HIV. Szczegółowy wykaz konkretnych schorzeń dających to uprawnienie aktualizowany i publikowany jest cyklicznie na specjalnej stronie internetowej poświęconej konwencji AERAS. Niemniej wolą ustawodawcy było dość szerokie nakreślenie grupy potencjalnych beneficjentów prawa do zapomnienia.

Nie ulega jednak wạtpliwości, że na pierwszy plan wysunięto interes osób, które przebyły chorobę nowotworową. Ostatni ustęp art. 1141-2 fr. k.z.p. wskazuje dość ogólnie, że każdy, kto z racji swojego stanu zdrowia lub upośledzenia znajduje się w grupie wyższego ryzyka, korzysta w pełni z konwencji AERAS. Z drugiej strony, art. 1141-5 fr. k.z.p. wskazuje wprost, że to rekonwalescenci onkologiczni mają prawo do niewspominania w deklaracji ubezpieczeniowej o chorobie nowotworowej, o ile ich leczenie jest zakończone. Wydaje się zatem zasadne ujęcie zaproponowane przez Marie Mesnil - w zależności od kwalifikacji zdrowotnej uprawnionego - prawa do zapomnienia sensu stricte, ${ }^{33}$ zarezerwowanego dla chorób nowotworowych, oraz prawa do zapomnienia dla innych grup pacjentów, pozostających poza nawiasem prawa do zapomnienia sensu stricte. Rozróżnienie to znajduje swoje uzasadnienie w ukształtowaniu przepisów kodeksu zdrowia publicznego i ma swoje istotne implikacje, o czym poniżej.

\subsubsection{Prawo do zapomnienia sensu stricte}

Prawo do zapomnienia jest prawem terminowym; termin ten zaczyna swój bieg od momentu zakończenia leczenia. Art. 1141-5 fr. k.z.p. odnosi się do fachowej terminologii medycznej - i określa ten moment jako chwilę zakończenia protokołu terapeutycznego. Istotny jest również fakt długotrwałej remisji choroby, która oznacza definitywne ozdrowienie i jednoczesny brak wznowy choroby czy pojawienia się przerzutów ${ }^{34}$.

Art. 1141-5 fr. k.z.p. przewiduje ogólny, dziesięcioletni termin, po upływie którego ubezpieczyciel nie może żądać od ubezpieczającego żadnych informacji związanych z leczeniem nowotworu. Jeśli choroba występowała przed 18. rokiem życia, termin ten ulega skróceniu do lat 5. Po upływie

32. Raport Démarches sociales et cancer, collection Guides patients Cancer info, INCa, janvier 2018.

33. M. Mesnil, op. cit., s. 123.

34. C. Torregosa i in., op. cit., s. 108. 
Prawo do zapomnienia - ewolucja francuskiego modelu normatywnego deklaracji ryzyka ...

terminu ubezpieczający ma dostęp do wszelkich usług ubezpieczeniowych na normalnych ogólnych warunkach umów. Co istotne, prawo to zwalnia ubezpieczającego z obowiązku deklaracji wyłącznie choroby nowotworowej, nie obejmujac jednak możliwych powikłań i następstw choroby, takich jak zaburzenia psychiczne czy niewydolności poszczególnych organów ${ }^{35}$. W efekcie, nawet jeśli fakt choroby nowotworowej jest znany ubezpieczycielowi, po upływie 10 lat nie może proponować składki w wysokości uwzględniającej ryzyko ponownego zachorowania czy pomijać w ofercie dodatkowych świadczeń czy gwarancji. Nieprzestrzeganie tego przepisu może narazić ubezpieczyciela na sankcje wskazane w przepisach wykonawczych kodeksu zdrowia publicznego $^{36}$ - m.in. ostrzeżenia, kary pieniężne czy czasowy zakaz wykonywania działalności.

\subsubsection{Prawo do zapomnienia sensu largo}

Prawo do zapomnienia dla pozostałych grup pacjentów - na potrzeby tego artykułu zwane prawem do zapomnienia sensu largo - będzie dotyczyć, idąc za rozumowaniem art. 1141-2 fr. k.z.p., wszystkiego, co kwalifikowane jako podwyższone ryzyko zdrowotne, zatem nie tylko chorób nowotworowych. W tym zakresie należy odnosić się do tabeli referencyjnych (fr. grille de référence) opracowywanych cyklicznie przez przedstawicieli instytucji kredytowych, ubezpieczeniowych oraz lekarzy, a publikowanych na rządowych stronach programów informacyjnych poświęconych konwencji AERAS. Tabela taka pełni w pewien sposób funkcję kwalifikatora, odsyłającego do terminów i uprawnień przysługujacych osobom z określonym podwyższonym ryzykiem zdrowotnym, w zależności od ryzyka. Tabela referencyjna jest opracowywana na podstawie danych przekazywanych przez Narodowy Instytut Raka (fr. Instutut National de Cancer), tak aby była adekwatna do najbardziej aktualnych możliwości diagnostycznych i terapeutycznych. Pierwsza tabela została opublikowana w lutym 2016 roku i obejmowała choroby takie jak rak piersi, rak jader, czy nosicielstwo wirusa HCV. Przykładowo, w okresie obowiązywania pierwszej tabeli referencyjnej, osoba będąca nosicielem tego wirusa mogła wnioskować o ubezpieczenie - korzystając z prawa do zapomnienia, czyli na standardowych warunkach (tak jak osoba zdrowa) po upływie terminu 48 tygodni od zakończenia leczenia. Po aktualizacji tabeli referencyjnej w marcu 2017 roku dostęp do prawa do zapomnienia mają także osoby chore na chłoniaka Hodgkina, nowotwór jelita grubego, nowotwór odbytu czy nosiciele HIV. ${ }^{37}$ Tabela referencyjna jest dla konsumentów usług ubezpieczeniowych ważnym narzędziem, gdyż na podstawie informacji w niej zawartych ubezpieczający może ocenić samodzielnie, czy upłynałł już czas dopuszczający przemilczenie odbytej choroby czy zakażenia, i w ten sposób chroni swoja prywatność, nie narażając się jednocześnie na zarzut zatajenia okoliczności wpływających na ocenę ryzyka przez ubezpieczyciela. Lista jednostek chorobowych ma charakter wyczerpujący, można zatem mówić o zamkniętym katalogu przesłanek dostępu do prawa do zapomnienia, podlegajacym jednak okresowej aktualizacji, o czym wspomniano powyżej.

Istotnym ograniczeniem z punktu widzenia treści prawa do zapomnienia sensu largo jest fakt, że zafunkcjonuje ono jedynie względem kredytów hipotecznych oraz umów kredytowych zawieranych w związku z prowadzoną działalnościa gospodarczą. Ponadto istnieją dodatkowe przesłanki,

35. M. Mesnil, op. cit., s. 124.

36. Dekret nr 2017-147 z 7 lutego 2017 r.

37. M. Mesnil, op. cit., s. 124. 
takie jak nieukończenie przez ubezpieczającego określonego wieku w momencie zakończenia ubezpieczanej czynności cywilnoprawnej lub ograniczenia kwotowe wysokości kredytów ${ }^{38}$.

\section{Wnioski}

\subsection{Francuski i polski model normatywny deklaracji ubezpieczeniowej}

Nie wdając się w dyskusję komparatystyczną, należy zauważyć, że polska regulacja z zasady bardzo podobnie do francuskiej kształtuje odpowiedzialność za prawdziwość deklaracji ubezpieczeniowej. Art. 21 i 22 ustawy o działalności ubezpieczeniowej kształtują mechanizm wzajemnej wymiany informacji przed zawarciem umowy ubezpieczenia ${ }^{39}$. Podobnie jak model francuski, polski system opiera się na systemie formularzowym, zwanym w ustawie „ankieta”. Art. 815 k.c. w bardzo podobny sposób reguluje odpowiedzialność ubezpieczającego za prawdziwość informacji zawartych w deklaracji ryzyka, która w przypadku istnienia złej wiary ubezpieczającego zwalnia ubezpieczyciela z odpowiedzialności.

Niuansem względem francuskiej regulacji, dostrzeżonym w trakcie dyskusji konferencyjnej40 przez Małgorzatę Serwach, jest art. 834 k.c., który sankcjonuje możliwość zaistnienia odpowiedzialności ubezpieczyciela także w razie podania przez ubezpieczającego informacji niezgodnych ze stanem rzeczywistym, po upływie trzyletniego kodeksowego terminu - lub krótszego, o ile umowa taki przewiduje. Przepis ten mógłby być rozumiany prima facie jako sankcjonowanie „kłamstwa w majestacie prawa”, gdyż zasadniczo - na podstawie art. 815 k.c. w celu zawarcia umowy ubezpieczenia należy wskazywać ubezpieczycielowi informacje prawdziwe. Niemniej w orzecznictwie polskich sądów broni się on jako bardzo efektywny środek ochrony osoby ubezpieczonej będącej pacjentem onkologicznym. W rozstrzygnięciu ${ }^{41}$ z 20 kwietnia 2018 roku Sąd Rejonowy w Łodzi uznał, że pozwany o wypłatę świadczenia ubezpieczyciel nie zdołał udowodnić, że ubezpieczona zataiła informacje na temat swojego zdrowia. Ubezpieczona zmarła żona powoda chorowała w 2000 roku na nowotwór piersi i została w pełni wyleczona, co potwierdzała dokumentacja medyczna. W 2011 roku z powodu bólów biodra rozpoczęła diagnostykę, skutkującą stwierdzeniem złamania kolca biodrowego. Umowa, z której powód - mąż zmarłej - wywodził roszczenie - została podpisana 1 lipca 2013 roku zaś trzy miesiące później stwierdzono u ubezpieczonej przerzut nowotworu do stawu biodrowego. Sąd zauważył, że „przystępując do przedmiotowego ubezpieczenia H.M. [ubezpieczona - przyp. aut.] zrezygnowała z wieloletniego ubezpieczenia na życie, które posiadała w [...] S.A., które już choćby przez pryzmat treści art. 834 k.c., gwarantowało wypłatę uposażonemu świadczenia z tytułu śmierci ubezpieczonej, niezależnie od jej przyczyn. Takie działanie, a więc rezygnacja z gwarantowanego świadczenia wypłacanego na wypadek śmierci, przy przyjęciu koncepcji pozwanego na temat wiarygodności złożonego przez H.M. oświadczenia, nie znajdowałoby żadnego racjonalnego uzasadnienia." Takie rozstrzygnięcie jest zgodne z teza postawiona przez Wojciecha Kamieńskiego, głoszącą iż polski model normatywny

38. Ibidem, s. 125.

39. E. Gniewek, P. Machnikowski, Kodeks cywilny. Komentarz, CH Beck, Warszawa 2014, s. 1478.

40. Konferencja naukowa „Oncologie et droit. Points de vue franco-polonais”, 9-10 listopada 2017 r. Wydział Prawa i Administracji Uniwersytetu Łódzkiego.

41. Sygn. VIII C 20/1?. 
Prawo do zapomnienia - ewolucja francuskiego modelu normatywnego deklaracji ryzyka ...

deklaracji ryzyka ubezpieczeniowego, oparty o art. 815 i 834 k.c. - uzupełniony domniemaniem dobrej wiary, przerzucającym ciężar dowodu ubezpieczyciela złej wiary ubezpieczającego na ubezpieczyciela oraz naturą umowy ubezpieczenia - jest mechanizmem zapewniającym efektywna ochronę ubezpieczonego ${ }^{42}$.

Ponadto pomocna w tym zakresie jest wygłoszona podczas dyskusji uwaga Małgorzaty PyziakSzafnickiej na temat ogólnych zasad polskiego prawa cywilnego dotyczących wad oświadczeń woli. Błąd czy podstęp skutkuje wzruszalnością umowy, którą podnieść można w terminie 1 roku od momentu powzięcia wiedzy o istnieniu wady. Oznacza to w konsekwencji, że czynność prawna może stać się niewzruszalna w krótkim terminie, dużo krótszym niż przewidziany art. 2224 fr. k.c. termin pięcioletni biegnący od momentu powzięcia wiedzy o przyczynie jej wzruszalności lub od momentu, kiedy z zachowaniem należytej staranności uprawniony mógł się o tym dowiedzieć. W ślad za tą uwagą można pokusić się o określenie polskiego modelu deklaracji ryzyka, jak i wad oświadczeń woli w ogóle jako regulacji oportunistycznych i przedkładających stabilność stosunku prawnego ponad sprawiedliwość relacji między stronami. Motywacją ustawodawcy wydaje się być jednak zapewnienie stabilności i efektywności ochrony ubezpieczeniowej - co w świetle natury umowy ubezpieczenia zasługuje na aprobatę.

\subsection{Ocena francuskiej regulacji prawa do zapomnienia}

Zbyt wcześnie jest na ocenę efektywności prawa do zapomnienia w zapewnieniu równego dostępu do usług bankowości ubezpieczeniowej. Z pewnościa jednak regulacja ta ma istotne znaczenie w świetle ogólnych zasad oceny ryzyka ubezpieczeniowego w prawie francuskim. 0 ile istotnie, historycznie zauważyć można tendencje prokonsumenckie - przede wszystkim w przejściu z systemu deklaracji spontanicznej do systemu formularzowego, z ugruntowanym przerzuceniem ciężaru dowodu na ubezpieczyciela - o tyle nie sposób nie zarzucić instytucji prawa do zapomnienia kazuistycznego charakteru. Wydaje się, że ustawodawca francuski w nieco sztuczny sposób próbuje usprawnić słabszą stronę umowy, która jest konsument usługi ubezpieczeniowej, mnożąc wyjątki oparte na "szansach” zdrowotnych poszczególnych grup chorych. Tymczasem prawo do zapomnienia sensu stricte, przewidujące pięcio - lub dziesięcioletni termin, po którym ubezpieczyciel traci możliwość gruntownej analizy stanu osobistego i zdrowotnego ubezpieczającego, jest dość prostym i jasnym środkiem prawnym gwarantującym rekonwalescentom onkologicznym prywatność i równy dostęp do usług sektora bancassurance. Koncepcja prawa do zapomnienia sensu largo, znajdująca swoje urzeczywistnienie w aktualizowanej tabeli referencyjnej, jest bez watpienia bardzo racjonalistyczna - oparta na przesłankach medycznych - niemniej trudno ocenić takie wartości, jak godność i równość człowieka na podstawie szacunkowych danych. Jak wskazuje Marie Mesnil, pewne grupy pacjentów czuły się pominięte i rozczarowane nieujęciem ich schorzeń w tabeli referencyjnej. ${ }^{43}$ Podobne idealizowanie racjonalizmu w traktatach dotyczących ochrony praw człowieka krytykowała Catherine Dupré: „Wysoce autonomiczny podmiot praw, narodzony z godnością, który idzie przez swoje teoretyczne życie, najwyraźniej bez wysiłku wyrażając swoje przekonania polityczne i prowadząc prywatne życie rodzinne, nie istnieje w rzeczywistości.

42. W. Kamieński, Wyłaczenie odpowiedzialności ubezpieczyciela z uwagi na przyczyny wypadku dotyczqce okresu przed rozpoczęciem ochrony ubezpieczeniowej, „Rozprawy Ubezpieczeniowe” 2015, nr 19, s. 33.

43. Ibidem, s. 126. 
Prawdziwe życie jest złożone i niechlujne; nie wszyscy ludzie rodzą się w godności, a wielu z nich żyje w nędzy i poniżeniu. Ludzie zapadają na różne choroby. Niektórzy z nich zdrowieją, ale niektórzy nie." ${ }^{44}$ Zadaniem i standardem dla ustawodawców powinno być tworzenie norm o charakterze generalnym i uniwersalnym, które znajdą zastosowanie w konkretnych przypadkach. Wydaje się, że samo prawo do zapomnienia sensu stricte spełniałoby funkcję uniwersalnej klauzuli ochronnej dla osób o podwyższonym ryzyku ubezpieczeniowym. Niemniej, z pewnością prawo do zapomnienia ma swoją bardzo pozytywną rolę w społeczeństwie - jest nią podniesienie świadomości praw osób chorujących przewlekle oraz cierpiących z powodu chorób nowotworowych. Przemilczenie choroby - także w tak prozaicznym momencie, jak wypełnianie deklaracji ubezpieczeniowej - będzie ulgạ dla osób odczuwających presję społeczną oraz podlegającym stygmatyzacji z powodu choroby czy zakażenia wirusem. ${ }^{45} \mathrm{~W}$ klasycznym scenariuszu przemilczenie mogłoby pociagać za sobą nieważność umowy ubezpieczenia, która zagrażałaby bezpieczeństwu ubezpieczonego. Prawo do zapomnienia w ubezpieczeniach jest wyrazem dążenia do zapewnienia poszanowania sprawiedliwości społecznej także na rynku ubezpieczeniowym.

\section{Podsumowanie}

Francuski ustawodawca nadał prawu do zapomnienia zgoła inne znaczenie niż ma ono w ogólnym rozporządzeniu o ochronie danych osobowych. Jest to próba pogodzenia interesów ubezpieczycieli - którzy korzystając ze swobody umów, maja prawo szacować ryzyko i decydować o zawarciu umowy - oraz konsumentów usług ubezpieczeniowych, których dobra osobiste, takie jak zdrowie i prywatność, nie powinny stać na przeszkodzie do równego dostępu do ubezpieczeń na życie. Prawo do zapomnienia - obok tajemnicy lekarskiej i zakazu przetwarzania danych genetycznych - ma gwarantować osobom cierpiącym z powodu chorób przewlekłych, w szczególności nowotworowych - uzyskanie efektywnej ochrony ubezpieczeniowej, polegającej na uchyleniu sankcji nieważności umowy.

\section{Wykaz źródeł}

\section{Publikacje książkowe:}

Fabre-Magnan M., Droit des obligations, Contrat et engagement unilatéral, Presses Universitaires de France, Paris 2016.

Gniewek E., Machnikowski P., Kodeks cywilny. Komentarz, CH Beck, Warszawa 2014.

Kowalewski E., Umowa ubezpieczenia, Oficyna Wydawnicza Branta, Bydgoszcz-Toruń 2002.

Laude A., Mathieu B., Tabuteau D., Droit de la santé, Presses Universitaires de France, Paris 2012. Rapport annuel 2011: Le risque, Cour de Cassation, Moury J. [red.], La Documentation française, Paris 2011.

44. C. Dupré, Unlocking human dignity: towards a theory for the 21st century, „European Human Rights Law Review" 2009, nr 2, s. 190-205.

45. C. Torregosa i in., op. cit., s. 110. 


\section{Artykuły:}

Dupré C., Unlocking human dignity: towards a theory for the 21st century, „European Human Rights Law Review" 2009, nr 2.

Groutel H., Preuve de la déclaration inexacte du risque et secret médical, „Médecine \& Droit” 2004, $n^{\circ} 68$.

Low L., King S., Wilkie T., Genetic discrimination in life insurance: empirical evidence from a cross sectional survey of genetic support groups in the United Kingdom, „General Practice”, vol. 31?, The BMJ Publishing Group, London 1998.

Kamieński W., Wyłaczenie odpowiedzialności ubezpieczyciela z uwagi na przyczyny wypadku dotyczqce okresu przed rozpoczęciem ochrony ubezpieczeniowej, „Rozprawy Ubezpieczeniowe” 2015, nr 19.

Marlewska B., Odpowiedzialność przedkontraktowa - reforma francuskiego prawa zobowiqzań z 2016 r., „Gdańskie Studia Prawnicze” 2018, tom XXXIX Współczesne problemy prawa prywatnego.

Mesnil M., What do we mean by the right to be forgotten? An analysis of the French case study from a lawyer's perspective, „Journal of Cancer Policy” 2018, nr 15.

Schneider M., Le plan cancer 2, „Oncologie” 2011, nr 13.

Torregosa C., Gesbert C., de Fallois M., Mamzer M.-F., Quel oubli pour les patients atteints de cancer?, „Ethics, Medicine and Public Health” 2017, nr 3.

\section{Strony internetowe:}

La Documentation française, Raport Narodowej Rady AIDS http://www.ladocumentationfrancaise. fr/var/storage/rapports-publics/044000249.pdf 


\section{The right to be forgotten - evolution of French normative model of risk disclosure duties in bancassurance sector}

The purpose of the article is to present the recent regulation of the right to be forgotten in French Public Health Code and its' impact on the client information duties within the life insurance contract.

The article is divided in two sections. In the first section, the author discusses the current principles governing information duties in insurance contracts, as well as their evolution under the influence of interpretative solutions developed by the Cour de Cassation. The shape of existing regulation has been discussed with reference to the relevant case law. In the second section, the author presents briefly two institutions that precede the right to be forgotten in the Public Health Code, as follows: the prohibition of genetic data disclosure and the professional medical secret. Finally, the right to be forgotten is discussed, both in terms of the scope of application and the content of the right. In conclusions, the right to be forgotten is compared briefly to relevant Polish law provisions.

The article includes references to the case law of the French Supreme Court and the predominantly French-language literature on the subject matter, which is justified by its content.

Key words: right to be forgotten, risk information disclosure, life insurance, French law, bancassurance.

MGR BARBARA MARLEWSKA - Wydział Prawa i Administracji Uniwersytetu Gdańskiego e-mail: b.marlewska@prawo.ug.edu.pl nr orcid (link) https://orcid.org/0000-0003-3762-2033?lang=en 